\section{OPEN ACCESS}

E-ISSN : 2549-6581

Artikel Hasil Penelitian

Diterima : 4 Juni 2017

Direview :10 Juni 2017

Dimuat : Agustus - November 2017
Journal of Issues in Midwifery

\title{
PENGARUH DUKUNGAN TENAGA KESEHATAN TERHADAP PEMBERIAN ASI EKSKLUSIF DI WILAYAH KERJA PUSKESMAS SISIR KELURAHAN SISIR KOTA BATU
}

\author{
Era Nurisa Windari ${ }^{1}$, Amalia Kusuma Dewi ${ }^{2}$, Siswanto ${ }^{2}$ \\ ${ }^{1}$ Program Studi Kebidanan Fakultas Kedokteran Universitas Brawijaya \\ ${ }^{2}$ Departemen IImu Kesehatan Masyarakat Fakultas Kedokteran Universitas Brawijaya \\ Email: ersawibowo@gmail.com
}

\begin{abstract}
Health personnel support is physical and physiologycal comfort, attention, appreciation and such a kind of another form of help that people accepted from health personnel. This kind of support can be either emotional support, appreciation, instrumental, and information. Health personnel can be a source of social support that comes from another individual who give support rarely and have a role that can change rapidly. Supporting mother to breastfeed is one of the important factor in exclusive breastfeeding. This study was a qualitative research aimed to analyze The Effect of Health Personnel Support for Exclusive Appropriation at Sisir Community Health Center (CHC) Working Area Batu City. This research design was assessed through analytical survey with cross sectional approach and was analyzed using Chi Square test. This research was conducted in August to September 2016. Sample of this research was selected using simple random sampling technique with a total sample of 100 mothers. The independent variabel of this research is health personnel support, and dependent variabel is the exclusive breastfeeding were measured using a questionnaire. Chi Square test result shows that $p=0.000(<0.05)$ and the ratio of 10.5 prevalent. It means the mother who has the support of health personnel lacked the possibility to not give breastfeeding 10,5 times greater than mother who hasn't received the support from health personnel. The conclusion of this study, there is a significant health personnel support for exclusive breastfeeding in Sisir Community Health Center Working Area Batu City.
\end{abstract}

Keywords:health personnel support, exclusive breastfeeding

\begin{abstract}
ABSTRAK
Dukungan tenaga kesehatan adalah kenyamanan fisik dan psikologis, perhatian, penghargaan, maupun bantuan dalam bentuk lainnya yang diterima individu dari tenaga kesehatan. Dukungan tenaga kesehatan dapat berwujud dukungan emosional, penghargaan, instrumental, dan informasi. Tenaga kesehatan merupakan sumber dukungan sosial yang berasal dari individu lain yang sangat jarang memberi dukungan dan memiliki peran yang sangat cepat berubah. Dukungan kepada ibu menjadi satu faktor penting dalam
\end{abstract}


memberikan ASI eksklusif. Penelitian ini bertujuan untuk menganalisa pengaruh dukungan tenaga kesehatan terhadap pemberian ASI eksklusif di wilayah kerja Puskemas Sisir Kota Batu. Desain penelitian adalah survey analitik dengan pendekatan cross sectional dan uji statistik menggunakan Chi Square. Penelitian ini dilakukan pada bulan Agustus sampai September 2016. Sampel dipilih dengan menggunakan teknik simple random sampling dengan jumlah sampel sebanyak 100 ibu. Variabel independen yaitu dukungan tenaga kesehatan dan variabel dependen yaitu pemberian ASI eksklusif yang diukur menggunakan kuesioner. Pada penelitian ini didapatkan $p=0,000(<0,05)$ dan ratio prevalen sebesar 10,5 hal ini berarti ibu yang mendapat dukungan tenaga kesehatan kurang mempunyai kemungkinan untuk tidak memberikan ASI eksklusif 10,5 kali lebih besar dari pada ibu yang mendapat dukungan tenaga kesehatan baik. Kesimpulan dari penelitian ini yaitu terdapat pengaruh dukungan tenaga kesehatan terhadap pemberian ASI eksklusif di wilayah kerja Puskesmas Sisir Kota Batu yang bermakna.

Kata kunci:dukungan tenaga kesehatan, ASI eksklusif

Korespondensi:Era Nurisa Windari. Surel:Email: ersawibowo@gmail.com

\section{PENDAHULUAN}

Dewasa ini cakupan pemberian ASI eksklusif di Indonesia tahun 2015 sebesar $55,7 \%$ masih jauh dari target pemerintah yaitu sebesar $80 \%$, meskipun $88,55 \%$ persalinan di Indonesia ditolong oleh tenaga kesehatan. Di Jawa Timur cakupan pemberian ASI eksklusif sebesar $74,1 \%{ }^{1,2}$.

Di wilayah kerja Puskesmas Sisir Kelurahan Sisir Kota Batu cakupan pemberian.ASI eksklusif masih rendah yaitu sebesar 50\%. Padahal ASI merupakan makanan terbaik dan sempurna yang mengandung zat-zat gizi berkualitas tinggi untuk kebutuhan tumbuh kembang bayi yang diberikan minimal sampai 6 bulan ${ }^{3}$.

Berdasarkan data yang diambil peneliti pada studi pendahuluan di Dinas Kesehatan Kota Batu, cakupan ASI eksklusif di Kota Batu pada tahun 2015 sebesar 75,4\%. Puskesmas Sisir memiliki 734 bayi yang seharusnya mendapatkan ASI eksklusif pada tahun 2015. Dari 734 bayi hanya 523 bayi yang mendapatkan ASI eksklusif. Selain itu, Puskesmas Sisir jika dibandingkan dengan 4 puskesmas lainnya memiliki cakupan ASI eksklusif dengan persentase paling rendah yaitu sebesar $71,3 \%{ }^{4}$.
Berdasarkan data yang diambil peneliti pada studi pendahuluan di Puskesmas Sisir Kota Batu, pada tahun 2015 Kelurahan Sisir memiliki cakupan ASI eksklusif dengan persentase paling rendah dari 2 desa lainnya yaitu sebesar 50\%. Berdasarkan data proyeksi balita, ibu hamil dan nifas Puskesmas Sisir per 11 April 2016, Kelurahan Sisir memiliki jumlah bayi usia 6 - 11 bulan paling banyak dari pada 2 desa lainya yaitu sebesar 156 bayi. Berdasarkan data posyandu Kelurahan Sisir Kota Batu bulan Agustus dan bulan September 2016, Kelurahan Sisir memiliki jumlah bayi usia 6 bulan - 1 tahun yaitu sebesar 129 Bayi.

ASI merupakan makanan yang paling sempurna untuk bayi karena ASI mengandung protein, lemak, karbohidrat, vitamin dan mineral dalam kadar yang sesuai sehingga mudah untuk dicerna dan diserap oleh bayi, selain itu ASI juga mengandung immunoglobulin yang berperan untuk mekanisme pertahanan terhadap bakteri dan virus, hormon pertumbuhan dan rangkaian asam lemak tak jenuh yang penting untuk perkembangan otak. Menurut WHO tahun 2011, ASI eksklusif adalah memberikan hanya ASI saja tanpa 
memberikan makanan dan minuman lain kepada bayi sejak lahir sampai berumur 6 bulan, kecuali obat dan vitamin. Menyadari banyaknya manfaat yang diperoleh oleh pemberian ASI eksklusif maka badan kesehatan dunia United Nation Children Fund (UNICEF) dan World Health Organization (WHO) merekomendasikan sebaiknya anak disusui hanya air susu ibu (ASI) selama paling sedikit 6 bulan $^{5}$. Di Indonesia, pemerintah juga telah menetapkan peraturan tentang pentingnya ASI eksklusif yang tercantum pada Keputusan Menteri Kesehatan Nomor 450/MENKES/SK/IV/2004 dan Peraturan Pemerintah (PP) Nomor 33 tahun $2012^{6}$.

Selain itu, menurut World Health Assembly (WHA) No 55.25 tahun 2002, standar emas makanan bayi adalah Inisiasi Menyusui Dini (IMD), ASI eksklusif, Makanan Pendamping ASI (MP-ASI) dan ASI diteruskan sampai 2 tahun atau lebih ${ }^{7}$. Penelitian yang dilakukan J. Lancet dan $\mathrm{K}$. Edmond menunjukkan bahwa secara keseluruhan pemberian makanan bayi berstandar emas dapat mengurangi $27,6 \%$ kematian bayi. IMD kematian bayi berkurang $8,6 \%$, ASI eksklusif kematian bayi berkurang 13\%, MP-ASI kematian bayi berkurang $6 \%^{8}$.

$$
\text { Menurut Rohani dalam }
$$

penelitianya bahwa dukungan kepada ibu menjadi satu faktor penting dalam memberikan ASI eksklusif. Jika ibu merasa senang dan lingkungan sekelilingnya tenang, maka ibu dapat merasa nyaman dalam memberikan ASI eksklusif ${ }^{9}$. Dukungan untuk ibu dapat diperoleh dari 3 pihak yaitu dukungan suami, dukungan keluarga, dan dukungan tenaga kesehatan. Dukungan tenaga kesehatan dapat berwujud dukungan emosional, penghargaan, instrumental, dan informasi ${ }^{10}$.
Sebuah penelitian menunjukkan ada hubungan yang bermakna antara dukungan bidan tentang pemberian ASI eksklusif dengan perilaku pemberian ASI eksklusif di wilayah kerja Puskesmas Ambarawa Kabupaten Semarang dengan nilai $p=$ $0,002^{11}$. Penelitian yang dilakukan Mamonto tahun 2015 menunjukan bahwa faktor peran tenaga kesehatan merupakan salah satu faktor yang berhubungan dengan pemberian ASI eksklusif pada bayi di wilayah kerja Puskesmas Kotobangon Kecamatan Kotamobagu Timur Kota Kotamobagu $^{12}$.

\section{METODE PENELITIAN}

Desain penelitian adalah survey analitik dengan pendekatan cross sectional. Teknik sampling yang digunakan adalah simple random sampling. Dalam penelitian ini digunakan sampel sebanyak 100 ibu yang memiliki bayi usia 6 bulan-1 tahun di wilayah kerja Puskesmas Sisir Kelurahan Sisir Kota Batu. Pengukuran variabel independen (dukungan Tenaga kesehatan) dan variabel dependen (pemberian ASI eksklusif) menggunakan kuisioner yang telah diuji validitas dan reliabilitas. Pengambilan data dilakukan pada bulan Agustus sampai September 2016. Teknik analisa data menggunakan uji statistik Chi Square dengan derajat kepercayaan $95 \%$ dengan $\alpha=0,05$.

\section{HASIL PENELITIAN}

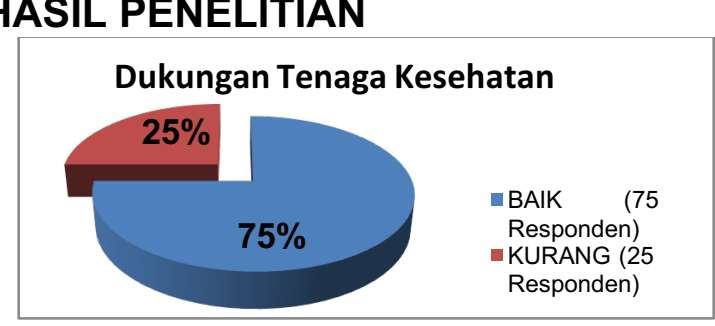

Gambar 1. Diagram Pie Dukungan Tenaga Kesehatan 
Berdasarkan gambar 1 di peroleh data bahwa dari 100 responden yang diteliti, sebagian besar ibu yang memiliki bayi usia 6 bulan-1 tahun mendapat dukungan tenaga kesehatan baik dengan prosentase sebesar $75 \%$ atau 75 responden.

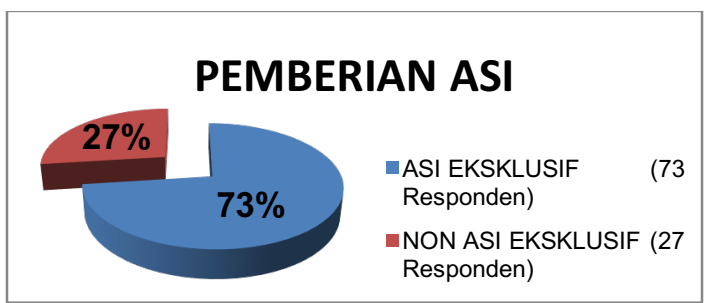

Gambar 2. Diagram Pie Pemberian ASI

Bersadarkan gambar 2 di peroleh data bahwa dari 100 responden yang diteliti, sebagian besar bayi mendapat ASI eksklusif dengan prosentase sebesar $73 \%$ atau 73 responden.

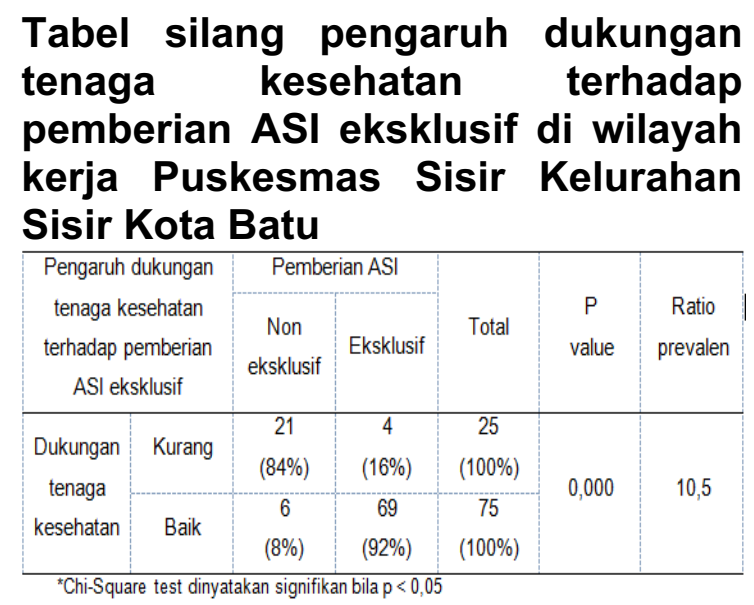

Dari Tabel diketahui bahwa ibu yang mendapatkan dukungan tenaga kesehatan kurang tidak memberikan ASI eksklusif $84 \%$ dibandingkan dengan dukungan tenaga kesehatan baik $8 \%(p=0,000)$. Pada penelitian ini juga dianalisa ratio prevalen, hasil menunjukan 10,5 hal ini berarti ibu yang mendapat dukungan tenaga kesehatan kurang mempunyai kemungkinan untuk tidak memberikan ASI eksklusif 10,5 kali lebih besar dari pada ibu yang mendapat dukungan tenaga kesehatan baik.
PEMBAHASAN

\section{Pengaruh Dukungan Tenaga Kesehatan Terhadap Pemberian ASI Eksklusif}

Berdasarkan data analisis penelitian yakni tabulasi silang 3.3, didapatkan hasil pengaruh dukungan tenaga kesehatan terhadap pemberian ASI eksklusif. Pada hasil analisis dipaparkan bahwa pengaruh dukungan tenaga kesehatan kadang tidak sesuai dengan harapan keberhasilan ASI eksklusif. Faktanya masih terdapat $27 \%$ yang tidak memberikan ASI eksklusif pada anaknya. Hal tersebut membuktikan bahwa masih terdapat faktor lain yang mempengaruhi keberhasilan pemberian ASI eksklusif.

Pada penelitian ini dilakukan uji statistik menggunakan Chi Square menunjukan $p$ value sebesar 0,000. Hal ini dapat disimpulkan bahwa ada pengaruh dukungan tenaga kesehatan terhadap pemberian ASI eksklusif di wilayah kerja Puskesmas Sisir Kelurahan Sisir Kota Batu, sehingga $\mathrm{H} 1$ diterima. Hal ini terjadi karena pengaruh dukungan tenaga kesehatan $75 \%$ dalam kategori baik terhadap pemberian ASI eksklusif, dengan rincian 69 responden memberikan ASI eksklusif dan 6 responden tidak memberikan ASI eksklusif. Sedangkan pada pengaruh dukungan tenaga kesehatan $25 \%$ dalam kategori kurang terhadap pemberian ASI eksklusif, dengan rincian 21 responden tidak memberikan ASI eksklusif dan 4 responden memberikan ASI eksklusif.

Pada penelitian ini juga dianalisa ratio prevalen, hasil menunjukan 10,5. Hal ini berarti ibu yang mendapat dukungan tenaga kesehatan kurang mempunyai kemungkinan untuk tidak memberikan ASI eksklusif 10,5 kali lebih besar dari pada ibu yang mendapat dukungan tenaga kesehatan baik. 
Hasil penelitian ini sesuai dengan teori faktor-faktor yang mempengaruhi pemberian ASI eksklusif salah satunya yaitu dukungan dari tenaga kesehatan. Hasil ini sejalan juga dengan penelitian yang dilakukan Mamonto tahun 2015 menunjukan bahwa faktor peran tenaga kesehatan merupakan salah satu faktor yang berhubungan dengan pemberian ASI eksklusif pada bayi di wilayah kerja Puskesmas Kotobangon Kecamatan Kotamobagu Timur Kota Kotamobagu $^{13}$. Penelitian yang dilakukan Maria (2016) di Tomohon Utara terdapat hubungan antara dukungan petugas dalam pemberian ASI eksklusif 6 bulan di wilayah kerja Puskesmas Kakaskasen Kecamatan Tomohon Utara Manado $P$ value = 0,029 . Penelitian yang dilakukan Anita (2016) di Tomohon Selatan menunjukkan hubungan antara dukungan petugas kesehatan dalam pemberian ASI eksklusif 6 bulan di wilayah kerja Puskesmas Pangolombian Kecamatan Tomohon Selatan $p$ value $=0,008^{14}$.

\section{DAFTAR PUSTAKA}

[1] Kementerian Kesehatan Republik Indonesia. 2015. Profil Kesehatan Indonesia tahun 2014. Jakarta: Kementerian Kesehatan Republik Indonesia.

[2] Keputusan Menteri Kesehatan Republik Indonesia. 2013. Kemenkes RI No 450/MENKES/SK/IV/2004 tentang pemberian Air Susu Ibu (ASI) secara eksklusif pada bayi Indonesia untuk mendukung pemberian Air Susulbu (ASI) Eksklusif.

[3] Puskesmas Sisir. 2015. Laporan Tahunan Gizi Puskesmas Sisir 2015. Batu.

[4] Puskesmas Sisir. 2016. Proyeksi Balita, Bumil dan Nifas Per 11 April 2016. Batu.
[5] World Health Organization (WHO). 2011. Pelatihan Konseling Menyusui Panduan Fasilitator. UNICEF.

[6] Peraturan Pemerintah Republik Indonesia Nomor 33 Tahun 2012 tentang Pemberian Air Susu Ibu Eksklusif. 1 Maret 2012. Lembaran Negara Republik Indonesia Tahun 2012 Nomor 58. Jakarta.

[7] WHA No 55.25. 2002. (Diakses pada tanggal 5 Maret 2016 dari http://www.selasi.org/).

[8] J. Lancet dan K. Edmond (dalam Sentra Laktasi Indonesia). 2003. (Diakses pada tanggal 5 Maret 2016 dari http://www.selasi.org/).

[9] Rohani. $2007 . \quad$ Pengaruh Karakteristik Ibu Menyusui Terhadap Pemberian ASI Eksklusif di Wilayah Kerja Teluk Kecamatan Secanggang Kabupaten Langkat Tahun 2007. (Diakses pada tanggal 12 Maret 2016 dari http://library.usu.ac.id).

[10] Sarafino, Edward. P. 2002. Health Psychology Biopsychological Interaction. 2nd ed. New John Wiley and Sons Inc.

[11] 11Ariwati $V$, Rosyidi $M$, Pranowowati P. 2014. Hubungan Dukungan Bidan Tentang Pemberian ASI Eksklusif Dengan Perilaku Pemberian ASI Eksklusif Di Wilayah Kerja Puskesmas Ambarawa Kabupaten Semarang. D-IV Kebidanan : STIKES Ngudi Waluyo Ungaran

[12] Mamonto T. 2015. Faktor-Faktor Yang Berhubungan Dengan Pemberian ASI Eksklusif Pada Bayi Di Wilayah Kerja Puskesmas Kotobangon Kecamatan Kotamobagu Timur Kota Kotamobagu. Program Pascasarjana IImu Kesehatan Masyarakat : Universitas Sam Ratulangi. 
[13] Maria, dkk. 2016. Hubungan antara umur ibu, pekerjaan ibu, pendapatan keluarga dan dukungan petugas dengan pemberian ASI eksklusif 6 bulan di Wilayah Kerja Puskesmas Kakaskasen Kecamatan Tomohon Utara. Manado : Pascasarjana Universitas Sam Ratulangi Manado.

[14] Anita, dkk. 2016. Hubungan pengetahuan ibu, fasilitas pelayanan kesehatan, dukungan keluarga dan dukungan petugas dengan pemberian ASI eksklusif 6 bulan di Wilayah Kerja Puskesmas Pangolombian Kecamatan Tomohon Selatan. Manado : Pascasarjana Universitas Sam Ratulangi Manado. 